\title{
Is Waste from Food Processing Industrial Meant for Throwing in Environment only: The Case of Apple Pomace
}

ISSN: 2640-9208

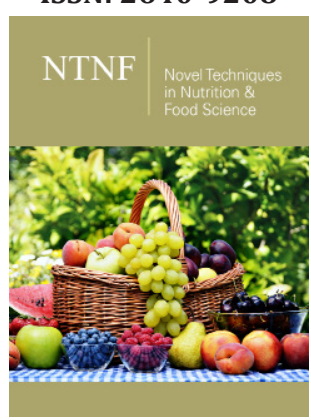

${ }^{* 1}$ Corresponding author: Joshi VK Retd Prof and Head, Department of Food Science and Techology ,DrYS Parmar university of Horticulture and Forestry,Nauni,Solan,India, India

Submission: 漹 January 28, 2019

Published: 侮 February 04, 2019

Volume 3 - Issue 2

How to cite this article: Joshi VK*. Is Waste from Food Processing Industrial Meant for Throwing in Environment only: The Case of Apple Pomace. Nov Tech Nutri Food Sci. 3(2).NTNF.000558.2019. DOI: 10.31031/NTNF.2019.03.000558

Copyright@ Joshi VK, This article is distributed under the terms of the Creative Commons Attribution 4.0 International License, which permits unrestricted use and redistribution provided that the original author and source are credited.

\section{Joshi VK*}

Department of Food Science and Technology, Dr YS Parmar university of Horticulture and Forestry, Solan ,India .

\section{Editorial}

Apple pomace is a left-over residue after juice extraction, containing peel, seed and remaining solid parts. It is a rich source of carbohydrates, dietary fibers, minerals and vitamin C [1]. The utilization of this waste into profitable manner and conversion into some useful product(s) holds a great promise rather than simply treating or disposing it off in the environment (Figure 1). The proper utilization of apple pomace would lead to the development of value-added products along with reduction in the pollution hazards indirectly. It would lead to establishment of industry based on the technologies developed providing job opportunities to the people of the area.

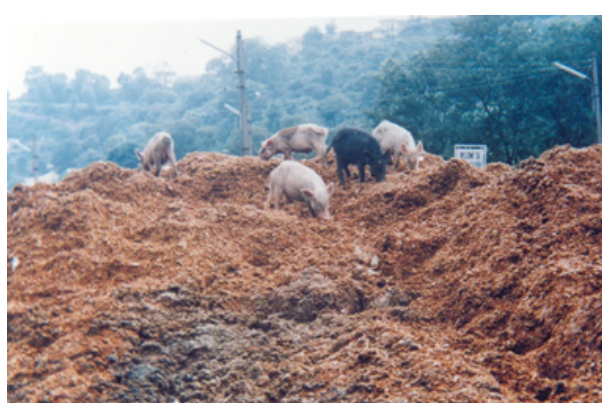

Figure 1: Apple pomace dumped outside a processing plant with pigs feeding on it.

Extensive efforts have been made to make use of the waste for production of various value-added product so that, the waste is generated in large quantities a single product is unlikely to be useful in this aspect. Therefore, several alternative techniques depending upon the capacity of the production unit were developed. Fermentative as well as non-fermentative utilization of apple pomace has been made a few years back which have now borne fruits [24]. These investigations have led to development of several technologies for the utilization of apple pomace. The research has shown that apple pomace can be converted into various edible products like sauce, jam and can be incorporated into the cookies to the extent of $20 \%$ as a source of dietary fibers [5,6]. But for making these products, the apple pomace has to be collected and preserved immediately after its production to avoid any contamination.

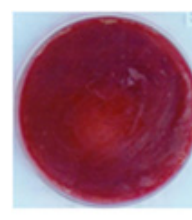

A

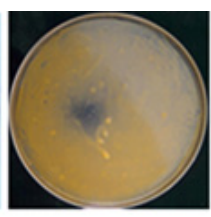

B

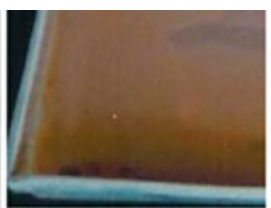

C

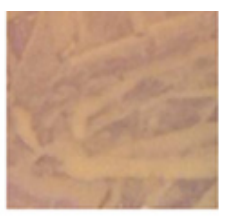

D
Figure 2: Color producing microorganisms grown on apple pomace based medium.

$\mathrm{A}=$ Chromobacter $\mathrm{sp}$. on a petriplate, $\mathrm{B}=$ Sarcina $\mathrm{sp}$. on a petriplate, $\mathrm{C}=$ Rhodotorula $\mathrm{sp}$. in tray, $\mathrm{D}=$ Micrococcus sp. in tray. 


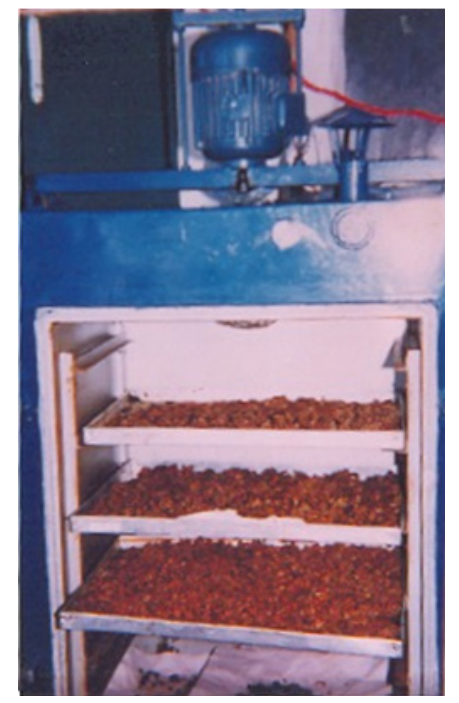

Figure 3: Drying of apple pomace in a mechanical drier.

On the bulk use of apple pomace, the research conducted has led to the development of technology where both ethanol and animal feed can be made $[3,8-10]$. The method includes the solidstate fermentation (SSF) of apple pomace, extracting the ethyl alcohol and drying the left-over material as animal feed [11-13]. The feed when evaluated for the poultry was found to be acceptable up to the level of $50 \%$. It has led to the growth of the chicks as per the standard poultry feed [14]. Color is the most important element in determining the acceptance and enhancing the acceptability of a food products [15]. As the synthetic color has been proved to be carcinogenic to humans, an increasing interest in the food colorants of natural origin have been developed. Despite the availability of variety of natural carotenoids from microorganism, microbial production is of great interest because of the problem of seasonal and geographical variability in the production and marketing of colorants of plant origin [16]. In addition to its suitability and safer alternative to the synthetic colors. Carotenoids also have anti-cancer activity and in the human diet their presence is being considered healthful because of their action as Pro-vitamin. Thus, there is a great need to utilize the waste not only to control the pollution but also to make natural colors, which are non-toxic in nature and good for health of consumer. Keeping these in mind, the studies on production and evaluation of microbial color using apple pomace have been undertaken successfully to isolate and characterize the microorganism for the production of various pigments to evaluate and characterize the pigment produced and optimize for production of various pigments to evaluate and characterize the pigment produced and optimize for production condition and to study the storage stability of color in the model solution (Figure 2). The apple pomace after drying (Figure 3) and grinding has been found to be a good substitute for an expensive media required for the growth of Rhodotorula as a microbial pigment [17]. The apple pomace has also supported the growth of pigment producing microorganism like Sarcina, Micrococcus, Chromobacter sp etc. [18]. The stability of the color in the model solution has also shown encouraging results
[19]. The pigment yield indicated that apple pomace to be a suitable substrate for pigment production with optimized condition but some work on aspect like toxicity etc. need to be taken in future.

Pectinestrase an enzyme used extensively in the food industry as juice clarifying agent is another value-added product for which pomace has been made using Aspergillus niger [20]. Apple pomace has been found suitable to produce baker's yeast. Comparison of different substrates to produce baker's yeast Saccharomyces cerevisiae was made and it was found that among the different substrates, apple pomace extract supported higher biomass yield though at par with jaggery [21]. Apple pomace was successfully employed as a substrate in medium to produce baker's yeast by a fed batch process (Figure 4). Conditions for the fed batch process have been optimized in fermenter bioflow-2000 [22].

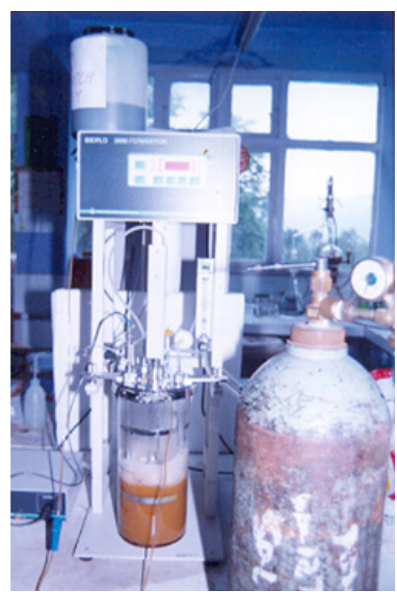

Figure 4: Production of Baker yeast from apple pomace using fad batch culture system in Bio flow 2000 fermenter.

Apple pomace has proved to be a good substrate for production of many enzymes like amylase, xylanase and cellulose [3]. Among pectinases. Pectin esterase is the enzyme these are that catalyses the hydrolysis of methylated carboxylic ester group of pectin into pectic acid and methanol [20]. Production of pectinase from apple pomace is promising due to several advantages like easy availability of cheaper raw material and easier processing of the substrate. Production of enzyme has been optimized in solid state fermentation of apple pomace. Tray as fermenter gave higher PME production than the flask. The evaluation of pectinases done in plum, peach, pear and apricot showed that the juice recovery of enzymatically treated pulp increased significantly.

Another product from apple pomace is the pectin which is used as a jelling agent in the preparation of various commercial products like jam, jelly, sauces, ketchup etc. [23]. Attempts have successfully been made to grow bakers' yeast which at present is being grown on the molasses based medium. Where apple pomace is available in plenty as compared to the molasses it could be used. The use of apple pomace for the bakers' yeast production could be a potential commercial product especially so when there is a demand for this product in the market. 
All these technologies have been developed on the laboratory scale and hold promise for industrial exploitation. The real purpose of research would be served when these are transferred to the ultimate user industry and is of the opinion that all out efforts should be made to transfer the technology to the industry. Apple pomace, at present is crying out for its immediate utilization. The technologies developed will pave the way for effective disposal of the waste, at the same time its utilization could result in the development of apple pomace-based industry. It will help in fighting the pollution caused by throwing the waste in the environment.

\section{References}

1. Joshi VK, Dev R, Vaidya D, Sharma Rakesh (2013) Apple pomace production, its composition and nutritive value. In: Bakshi AK, Joshi VK, Vaidya D (Eds.), Food Processing and Preservation, Book Agency, New Delhi, India, pp. 427-441.

2. Joshi VK, Rana N, Devi MP (2009) Technology for utilization of apple pomace: A waste from apple juice processing industry. Indian food Industry 28(4): 1-10.

3. Joshi VK, Sharma SK (2011) Food processing wastes management. New India Publishing Agency, Pitam Pura, New Delhi, India, p. 472.

4. Joshi VK (1998) Apple pomace utilization: Present status and future strategies. In: Ashok Pandey (Ed.), Advances in Biotechnology, Educational Publish \& Distributors, New Delhi, India, pp. 141-155.

5. Joshi VK, Kaushal NK (1994) Composition of apple pomace standardization of pulp making preparation and evaluation of apple jam. Res Ind 40: 203-207.

6. Joshi VK, Kaushal NK, Thakur NS (1996) Apple pomace sauce: Development and quality of fresh and stored products. J Food Sci Technol 33(5): 414-417.

7. Joshi VK, Sandhu DK (1996) Preparation and evaluation of animal feed using solid state fermentation of apple pomace. Bioresource Technol 56: 251-255.

8. Joshi VK, Sandhu DK (1994) Solid state fermentation of apple pomace for production of ethanol and animal feed. In: A Pandey (Ed.), Solid State Fermentation, Eastern Wiley Pub Co, India, pp. 93-98.

9. Joshi VK, Sandhu D, Jaiswal S (1995) Effect of addition of $\mathrm{SO}_{2}$ on solid state fermentation of apple pomace. Cur Science 69(3): 263-264.

10. Devarajan A, Joshi VK, Gupta K, Shekhar C, Lal BB (2002) Evaluation of apple pomace based reconstituted feed in rats after solid state fermentation and ethanol recovery. Brazilian Archives of Biology Technology 47(1): 93-106
11. Joshi VK, Devranjan A, Sharma N (2013) Solid state fermentation of apple pomace: the effect of sequential interactive co-culture system on solid state fermentation behavior and physico-chemical characteristics. Journal of Hill Research 26(1-2): 43-55.

12. Sandhu DK, Joshi VK (1997) Solid state fermentation of apple pomace for concomitant production of ethanol and animal feed. J Sci Ind Res 56: 86-90.

13. Joshi VK, Sandhu DK (1996) Effect on type of alcohols in the distillates from the solid-state fermentation of apple pomace by different yeasts. Natl Acad Sci Letters 49(11-12): 219-224.

14. Joshi VK, Gupta K, Devarajan A, Lal BB, Arya SP (1999) Production and evaluation of fermented apple pomace feed in broilers. J Food Sci Technol 37(6): 609-612.

15. Joshi VK, MP Devi, Devender A, Sharma R (2012) Bicolor: chemistry, production, safety and market potential. In: Joshi VK, Singh RS (Eds.), Food Biotechnology: Principles and Practices, IK Publishers, New Delhi, India, pp. 641-689.

16. Joshi VK (2002) Food processing waste management-opportunities and challenges. In: JK Arora, SS Marwaha, Grover R (Eds.), Biotechnology in Agriculture and Environment. Asia Tech Publishers and Distributors, New Delhi, India, pp. 129-148.

17. Sandhu DK, Joshi VK (1996) Development of apple pomace medium optimization of conditions for pigment production by Rhodotorula. Adv Food Res 19(1-2): 31-34.

18. Devender A, Joshi VK (2005) Optimization of apple pomace based medium and fermentation conditions for pigment production by chromobacter species. J Food Sci Technol 43(5): 515-520.

19. Devender A, Joshi VK (2005) Optimization of apple pomace based medium and fermentation conditions for pigment production by Micrococcus species. J Sci Ind Res 64: 598-601.

20. Joshi VK, Pandey A, Sandhu DK (1999) Food factory waste management technology. In: VK Joshi, Ashok P (Eds.), Biotechnology: Food Fermentation, Educational Publishers and Distributors, New Delhi, India, 2: 1291-1348.

21. Bhushan S, Kasana RC, Joshi VK (2012) Baker's yeast production. In: Joshi VK, Singh RS (Eds.), Food Biotechnology: Principles and Practices. IK International Publishing House, New Delhi, India, pp. 471-494.

22. Shashi B, Joshi VK (2006) Baker's yeast production under fed batch culture from apple pomace. J Sci Ind Res 65(1): 72-76.

23. Joshi C, Joshi VK (1990) Food processing waste management technology. Indian Food Packer 44(5): 56-67. 